\title{
INTERACTION OF ARSENIC ON ALKALINE PHOSPHATASE ACTIVITY IN PERIPHERAL TISSUES OF COLD EXPOSED FISHES (Channa punctatus)
}

\author{
S. K. Roy ${ }^{1}$, M. S. Haque ${ }^{2, *}$ and M. A. Haque ${ }^{3}$ \\ Department of Biochemistry and Molecular Biology, Rajshahi University \\ Rajshahi-6205, Bangladesh
}

\begin{abstract}
Channa punctatus variety of fishes were exposed to low temperature $\left(4 \sim 8^{\circ} \mathrm{C}\right)$ for $30 \mathrm{~min}, 1 \mathrm{~h}, 2 \mathrm{~h}$ and $4 \mathrm{~h}$ which is highly energetic and can survive in the critical situations. Very low or no significant alkaline phosphatase (ALKP) activities in skeletal muscle were found, however, in heart, the activities were seemed to be reduced after prolonged exposure in cold. In liver, the activities were enhanced by $71.8,125.3,116.9$ and $114.1 \%$ significantly $(\mathrm{P}<0.05)$ compared to control fishes kept in ambient environmental temperature and found to be higher for $1 \mathrm{~h}$ of cold. Similar stimulatory effects $(7.6,49.5$ and $150.4 \%$ ) of ALKP activity in gastrointestinal tract of fishes were found whenever the fishes were exposed to cold for $30 \mathrm{~min}, 1 \mathrm{~h}$ and $2 \mathrm{~h}$, respectively, while $29.7 \%$ reduced activity was demonstrated after $4 \mathrm{~h}$ of the treatment. To clarify whether arsenic impairs in cold-induced metabolic functions in peripheral tissues, groups of fishes were exposed to $100 \mathrm{mM} \mathrm{Na}_{2} \mathrm{HAsO}_{4}$ as well as in cold. Very low responses of arsenic on enzyme activity in skeletal muscle and heart were observed and appeared to be reduced when compared to control. In liver, ALKP activity was augmented significantly $(\mathrm{P}<0.05)$ by arsenic treatment and also by cold, however, the effects were more pronounced in cold when compared to arsenic treated alone while the enhanced activity in gastrointestinal tract in response to cold was almost completely abolished by arsenic treatment. As a result, a new insight was found for the regulation of adaptive response in peripheral tissues to environmental temperature and arsenic might be involved in interaction of cold induced effects.
\end{abstract}

Key Words: Arsenic exposure, Sympathetic innervations, Low temperature, Peripheral tissues, Metabolic regulation

\section{INTRODUCTION}

Snake heads fish (Channa punctatus) is generally found in freshwater of ponds, beel, haor, reservoir in Bangladesh. They are much energetic and survive in the critical circumstances for long time. They are one of the major sources of protein in the diet for

${ }^{1}$ and ${ }^{2}$ Department of Biochemistry and Molecular Biology, University of Rajshahi, Rajshahi-6205, Bangladesh

3 Department of Biotechnology, BSMRAU, Salna, Gazipur, Bangladesh

* Corresponding author. E-mail: haque_drshahidul@yahoo.co.in 
human being specially in rural areas. It is assumed that the higher energy content of this fish is caused by the increased activity of the sympathetic nerves (Bray, 1999 and Flechtner-Mors et al., 1999). During environmental low temperature, it is assumed that the peripheral tissues might be involved critically and coordinately on their regulation of metabolites to survive in the atmosphere (Haque et al., 2009). Although fishes are exposed to various environmental stimuli, the species wants to maintain the homeostasis of the body. Adaptive thermogenesis, the dissipation of energy in the form of heat in response to external stimuli, has been implicated in the regulation of energy balance and body temperature. In shivering thermogenesis, because of the higher oxidative process, generation of ATP rather than UCP is predominant and hydrolysis of ATP yields energy for living in the atmosphere. Therefore, it is generally accepted that the organisms survive in the critical environment by different mechanisms and varies species to species. However, the mechanism involving the adaptive response in this species is not clarified. The peripheral tissues play the important roles in metabolic regulation. The enhanced nerve activity in response to cold is involved in regulation of metabolic activities in skeletal muscle, heart, liver, GIT (gastrointestinal tract) as well as in other peripheral tissues. The increased nerve activity in liver has been involved in changes of degradation of cellular ATP (Westfall et al., 2000). Moreover, liver glycogen metabolism is influenced in response to cold. Higher degradation of liver glycogen releases energy available for doing mechanical work and survive in the critical circumstances of the environment.

Arsenic is toxic to the living organisms. Prolonged exposure of arsenic has detrimental effects in tissues. It may impair the glycolysis as well as the oxidative processes (Tchounwou et al., 2003) and causes different types of pathogenic syndromes in rodents, fishes and other organisms. Exposure of higher concentration of arsenic in water may also cause severe effects in fish and might be involved in producing cancer or other cellular effects. However, the mechanism underlying the effects of acute arsenic exposure on the regulation of oxidative and glycolytic processes in tissues of fishes exposed to cold is not known. Arsenic is classified as a human carcinogen based on several epidemiological studies showing an association of arsenic exposure with cancers in lung, bladder, kidney and liver (Hughes, 2002 and Tchounwou et al., 2003). Moreover, fish have long been used as sentinels for biomonitoring of aquatic environmental pollutants and are good indicators of arsenic toxicity (Tisler and Zagorc-Koncan, 2002). The regulation of metabolic activities in peripheral tissues in response to the changes of temperature is an important aspect in fish and to clarify the role of arsenic in cold-induced metabolic functions responsible for survive of the species in the environment- the current protocol was designed for investigation.

\section{MATERIALS AND METHODS}

\section{Fishes}

Taki fish (Channa punctatus) weighing $50 \mathrm{~g}$ to $60 \mathrm{~g}$ were used. They are maintained in normal water. In the day of experiment, cold exposure $\left(4 \sim 8^{\circ} \mathrm{C}\right)$ was given to the different groups of fishes in the cold chamber for $30 \mathrm{~min}, 1 \mathrm{~h}, 2 \mathrm{~h}$ and $4 \mathrm{~h}$ period with full aeration 
and with free access of water. After cold exposure treatment, fishes were quickly decapitated and the peripheral tissues including skeletal muscle from the dorsal part, liver, heart and gastrointestinal tract (GIT) were sampled carefully and taken weight by digital balance (Chyo, JL-180, China) and kept at $-20^{\circ} \mathrm{C}$. Control fishes were similarly used for sampling of tissues except giving cold exposure.

\section{Arsenic treatment}

To examine the role of arsenic on the regulation of metabolic activities in liver, skeletal muscle, heart and GIT, groups of fishes were exposed with arsenic compound (100 mM $\mathrm{Na}_{2} \mathrm{HAsO}_{4} 7 \mathrm{H}_{2} \mathrm{O}$, BDH Chemical Ltd.) in cold for $1 \mathrm{hr}$. The respective other groups of fishes were treated with only $100 \mathrm{mM}$ of arsenic compound $\left(\mathrm{Na}_{2} \mathrm{HAsO}_{4}\right)$ for $1 \mathrm{hr}$ in ambient temperature. The tissues were sampled after the treatment similarly as mentioned above.

\section{Assay of alkaline phosphatase activity}

Tissues were homogenized with pre-cooled water and were centrifuged at $8000 \mathrm{rpm}$ for $10 \mathrm{~min}$. The supernatants from each tissue homogenate were used as crude extract for assay of alkaline phosphatase activity which was determined by using 100 200 $\mu \mathrm{L}$ extract. The enzyme activity was determined as described by Ramnik (1999). Briefly, 0.25 $\mathrm{mL}$ of PNPP $(1.2 \mathrm{mg} / \mathrm{mL}$ in glycine-NaOH buffer, $\mathrm{pH} 10.0)$ was added to $0.5 \mathrm{~mL}$ glycine$\mathrm{NaOH}$ buffer (pH 10.0) and incubated for $5 \mathrm{~min}$ at $37^{\circ} \mathrm{C}$. 100 200 $\mu \mathrm{L}$ of tissue extract was taken to the solution and for blank, same volume of buffer was used in place of tissue extract and incubated for $30 \mathrm{~min}$. After incubation, it was made up to $4 \mathrm{~mL}$ with $0.1 \mathrm{~N}$ $\mathrm{NaOH}$ solution and absorbance was taken at $410 \mathrm{~nm}$. The amount of PNP (p-nitrophenol) produced after hydrolysis of PNPP (p-nitrophenyl phosphate) by the enzyme was measured from the standard PNP solution $(500 \mu \mathrm{mol} / \mathrm{L}$ in buffer, $\mathrm{pH} 10.0)$. The enzyme activity is expressed as $\mu \mathrm{mol}$ of $\mathrm{PNP} / \mathrm{min} / \mathrm{g}$ of tissue.

\section{Statistical analysis}

Results of the experiments were expressed as mean and standard error of different groups. The differences between the mean values were evaluated by ANOVA followed by paired t-test with SPSS software.

\section{RESULTS}

Time course effect of low temperature on the regulation of ALKP activity in skeletal muscle

To examine the role of cold exposure on the regulation of ALKP activity in peripheral tissues, the fishes were exposed to cold for $30 \mathrm{~min}, 1 \mathrm{~h}, 2 \mathrm{~h}$, and $4 \mathrm{~h}$ in the cold chamber. For control fish kept in ambient temperature, ALKP activity in skeletal muscle was 0.036 $\pm 0.01 \mu \mathrm{mol} / \mathrm{min} / \mathrm{g}$ of tissue. After $30 \mathrm{~min}$ and $1 \mathrm{~h}$ exposure of cold, the values were 0.024 \pm 0.02 and $0.049 \pm 0.01 \mu \mathrm{mol} / \mathrm{min} / \mathrm{g}$ of tissue respectively. No significant changes of ALKP activity in response to cold were found. Groups of fishes exposed to cold for $2 \mathrm{~h}$ 
and $4 \mathrm{~h}$ had enzyme activities $0.028 \pm 0.01$ and $0.005 \pm 0.001 \mu \mathrm{mol} / \mathrm{min} / \mathrm{g}$ of tissue respectively in their tissues. ALKP activity in skeletal muscle was found to be very low and seems to be reduced in response to cold (Table 1).

Table 1. Effect of low temperature on alkaline phosphatase (ALKP) activity in skeletal muscle of fishes. The fishes were exposed to cold for $30 \mathrm{~min}, 1 \mathrm{~h}$ and $2 \mathrm{~h}$ and $4 \mathrm{~h}$ in the cold chamber. After the treatment, the fishes were immediately decapitated and sampling of tissue was performed. Control fishes were similarly used except giving cold exposure

\begin{tabular}{lc}
\hline \multicolumn{1}{c|}{ Treatments } & $\begin{array}{c}\text { Alkaline phosphatase activity } \\
(\mu \mathrm{mol} / \mathrm{min} / \mathrm{g} \text { of tissue })\end{array}$ \\
\hline Control & $0.036 \pm 0.01$ \\
$30 \mathrm{~min}$ & $0.024 \pm 0.02$ \\
$\mathrm{~h}$ & $0.049 \pm 0.01$ \\
$2 \mathrm{~h}$ & $0.028 \pm 0.01$ \\
$4 \mathrm{~h}$ & $0.005 \pm 0.001$ \\
\hline
\end{tabular}

The data are means \pm SE for 4 fishes in each group. No significant changes of ALKP in response to cold were observed when compared to control

Time course effect of low temperature on the regulation of ALKP activity in heart muscle

As shown in Table 2, the average ALKP activities in heart of fishes exposed to cold for 30 $\min , 1 \mathrm{~h}, 2 \mathrm{~h}$ and $4 \mathrm{~h}$ were $0.366 \pm 0.08,0.058 \pm 0.02,0.026 \pm 0.02$ and $0.073 \pm 0.03$ $\mu \mathrm{mol} / \mathrm{min} / \mathrm{g}$ of tissue respectively while for the control fish, the activity was $0.246 \pm 0.01$ $\mu \mathrm{mol} / \mathrm{min} / \mathrm{g}$ of tissue. No significant change of enzyme activity for $30 \mathrm{~min}$ of cold exposure was found, however, the reduced activities in response to cold for $1 \mathrm{~h}(\mathrm{P}<0.05)$, $2 \mathrm{~h}(\mathrm{P}<0.01)$ and $4 \mathrm{~h}(\mathrm{P}<0.05)$ were observed when compared to the control fishes. The results demonstrate that low temperature might be involved in reducing enzyme activity in heart during prolonged exposure of cold and could be correlated to the impaired synthesis of protein in mitochondria.

Table 2. Effect of low temperature on alkaline phosphatase (ALKP) activity in heart of fishes. The fishes were exposed to cold for $30 \mathrm{~min}, 1 \mathrm{~h}$ and $2 \mathrm{~h}$ and $4 \mathrm{~h}$ in the cold chamber. After the treatment, the fishes were immediately decapitated and sampling of tissue was performed. Control fishes were similarly used except giving cold exposure

\begin{tabular}{l|c}
\hline \multicolumn{1}{c|}{ Treatments } & $\begin{array}{c}\text { Alkaline phosphatase activity } \\
(\mu \mathrm{mol} / \mathrm{min} / \mathrm{g} \text { of tissue })\end{array}$ \\
\hline Control & $0.246 \pm 0.01$ \\
$30 \mathrm{~min}$ & $0.366 \pm 0.08$ \\
$\mathrm{~h}$ & $0.058 \pm 0.02^{\mathrm{A}}$ \\
$2 \mathrm{~h}$ & $0.026 \pm 0.02^{\mathrm{B}}$ \\
$4 \mathrm{~h}$ & $0.073 \pm 0.03^{\mathrm{A}}$ \\
\hline
\end{tabular}

The data are means $\pm \mathrm{SE}$ for 4 fishes in each group. $\mathrm{AP}^{\mathrm{P}}<0.05$, $\mathrm{BP}<0.01$ versus control 
Time course effect of low temperature on the regulation of alkaline phosphatase (ALKP) activity in liver

Groups of fishes were used to examine the role of low temperature on the changes of ALKP activity in liver. As shown in Table 3, ALKP activities in response to cold for 30 min and $1 \mathrm{~h}$ were $0.610 \pm 0.02$ and $0.800 \pm 0.07 \mu \mathrm{mol} / \mathrm{min} / \mathrm{g}$ of tissue respectively while for $2 \mathrm{~h}$ and $4 \mathrm{~h}$ in cold, the activities were $0.770 \pm 0.06$ and $0.760 \pm 0.10 \mu \mathrm{mol} / \mathrm{min} / \mathrm{g}$ of tissue respectively. For control fishes, the activity was $0.355 \pm 0.08 \mu \mathrm{mol} / \mathrm{min} / \mathrm{g}$ of tissue weight. A significant 71.8\% $(\mathrm{P}<0.05)$ and $125.3 \%(\mathrm{P}<0.001)$ enhanced ALKP activities in liver were found after $30 \mathrm{~min}$ and $1 \mathrm{~h}$ respectively and $116.9 \%(\mathrm{P}<0.05)$ and $114.1 \%$ $(\mathrm{P}<0.05)$ increased activities after $2 \mathrm{~h}$ and $4 \mathrm{~h}$ were found respectively compared to the liver of control fishes. However, higher activity was observed after $1 \mathrm{~h}$ of cold. Cold exposure stimulates enzyme activity time dependently up to $1 \mathrm{~h}$. The changes of liver ALKP in response to cold might be involved in the regulation of liver metabolic functions. The alteration of ALKP in liver is an index for characterization of the sensitivity to the environmental temperature.

Table 3. Changes of alkaline phosphatase (ALKP) activity in liver of fishes exposed to cold. The fishes were exposed to cold for $30 \mathrm{~min}, 1 \mathrm{~h}$ and $2 \mathrm{~h}$ and $4 \mathrm{~h}$ in the cold chamber. After the treatment, the fishes were immediately decapitated and sampling of tissue was performed. Control fishes were similarly used except giving cold exposure

\begin{tabular}{lcc}
\hline \multicolumn{1}{c|}{ Treatments } & $\begin{array}{c}\text { Alkaline phosphatase activity } \\
(\mu \mathrm{mol} / \mathrm{min} / \mathrm{g} \text { of tissue })\end{array}$ \\
\hline Control & $0.355 \pm 0.08$ \\
$30 \mathrm{~min}$ & $0.610 \pm 0.02^{\mathrm{A}}$ \\
$1 \mathrm{~h}$ & $0.800 \pm 0.07 \mathrm{~B}$ \\
$2 \mathrm{~h}$ & $0.770 \pm 0.06^{\mathrm{A}}$ \\
$4 \mathrm{~h}$ & $0.760 \pm 0.10^{\mathrm{A}}$ \\
\hline
\end{tabular}

The data are means $\pm \mathrm{SE}$ for 4 fishes in each group. ${ }^{\mathrm{AP}}<0.05$ versus control; $\mathrm{BP}<0.001$ versus control

Time course effect of low temperature on the regulation of alkaline phosphatase (ALKP) activity in GIT

To clarify whether cold exposure is involved in the regulation of ALKP in GIT, fishes were exposed to cold and the activity of enzyme in the extract of tissue of fishes for 30 $\min , 1 \mathrm{~h}, 2 \mathrm{~h}$ and $4 \mathrm{~h}$ were $0.640 \pm 0.04,0.890 \pm 0.12,1.490 \pm 0.71$ and $0.418 \pm 0.03$ $\mu \mathrm{mol} / \mathrm{min} / \mathrm{g}$ of tissue respectively while for the control fish, the value was $0.595 \pm 0.05$ $\mu \mathrm{mol} / \mathrm{min} / \mathrm{g}$ of tissue (shown in Table 4). Similar to liver, the increase in activity in response to cold in this tissue was found up to $2 \mathrm{~h}$. The enhanced enzyme activities in cold for $30 \mathrm{~min}, 1 \mathrm{~h}$ and $2 \mathrm{~h}$ were $7.56 \%, 49.5 \% \quad(\mathrm{P}<0.05)$ and $150.42 \% \quad(\mathrm{P}<0.05)$ respectively, on the other hand, $29.74 \%(\mathrm{P}<0.01)$ reduced activity after $4 \mathrm{~h}$ was found compared to the tissue of control fishes, however, maximal response of activity was 
observed after $2 \mathrm{~h}$ of cold. Cold exposure stimulates the enzyme activity in this tissue time dependently up to $2 \mathrm{~h}$. The changes of ALKP activity in response to cold might be involved in the regulation of GIT metabolic functions.

Table 4. Changes of alkaline phosphatase (ALKP) activity in gastrointestinal tract (GIT) of fishes exposed to cold. The fishes were exposed to cold for $30 \mathrm{~min}, 1 \mathrm{~h}$ and $2 \mathrm{~h}$ and $4 \mathrm{~h}$ in the cold chamber. After the treatment, the fishes were immediately decapitated and sampling of tissue was performed. Control fishes were similarly used except giving cold exposure

\begin{tabular}{l|c}
\hline \multicolumn{1}{c|}{ Treatments } & $\begin{array}{c}\text { Alkaline phosphatase activity } \\
(\mu \mathrm{mol} / \mathrm{min} / \mathrm{g} \text { of tissue })\end{array}$ \\
\hline Control & $0.595 \pm 0.05$ \\
$30 \mathrm{~min}$ & $0.640 \pm 0.04$ \\
$1 \mathrm{~h}$ & $0.890 \pm 0.12^{\mathrm{A}}$ \\
$2 \mathrm{~h}$ & $1.490 \pm 0.71^{\mathrm{A}}$ \\
$4 \mathrm{~h}$ & $0.418 \pm 0.03^{\mathrm{B}}$ \\
\hline
\end{tabular}

The data are means \pm SE for $4 \sim 5$ fishes in each group; ${ }^{\mathrm{P}}<0.05$ versus control; $\mathrm{B} P<0.01$ versus control

\section{Role of arsenic (100 mM Na2HAsO4) on ALKP activity in cold-induced skeletal muscle and heart}

Groups of fishes were used to examine the role of arsenic on the changes of ALKP activity in skeletal muscle. The ALKP activity of arsenic-treated fishes for $1 \mathrm{~h}$ was $0.01 \pm 0.002$ $\mu \mathrm{mol} / \mathrm{min} / \mathrm{g}$ of tissue where as for control fishes; the value was $0.036 \pm 0.01 \mu \mathrm{mol} / \mathrm{min} / \mathrm{g}$ of tissue. As shown in Fig. 1, the activity in response to arsenic was found to be reduced $(P=0.05)$ although the value was very low in this tissue. Groups of fishes were exposed to cold with arsenic solution and the activity in skeletal muscle was $0.005 \pm 0.001$ $\mu \mathrm{mol} / \mathrm{min} / \mathrm{g}$ of tissue and that of the cold exposed fishes only $0.049 \pm 0.001 \mu \mathrm{mol}$. The activity in response to arsenic was found similarly to be reduced when compared to control and the respective cold exposed fishes. The results indicated that the ALKP activity in skeletal muscle was very low, however, $\mathrm{Na}_{2} \mathrm{HAsO}_{4}$ might be involved in reducing the activity and arsenic causes also the lower response in such adverse environmental condition.

To examine the role of arsenic on ALKP level in heart, the fishes were exposed to $100 \mathrm{mM}$ $\mathrm{Na}_{2} \mathrm{HAsO}_{4}$ solution for $1 \mathrm{~h}$ and also the respective group was induced by cold. As shown in Fig. 2, ALKP activity in heart muscle of fishes exposed to arsenic was $0.171 \pm 0.06$ $\mu \mathrm{mol} / \mathrm{min} / \mathrm{g}$ of tissue while for the control fishes, the value was $0.246 \pm 0.01$ $\mu \mathrm{mol} / \mathrm{min} / \mathrm{g}$ of tissue and for cold exposed heart, the value was $0.058 \pm 0.02 \mu \mathrm{mol} / \mathrm{min} / \mathrm{g}$ of tissue. The ALKP activity in heart of arsenic-treated fish was reduced (30.5\%) 
significantly $(\mathrm{P}<0.1)$ than in heart of control fish. Fishes exposed to cold with arsenic had $0.075 \pm 0.02 \mu \mathrm{mol} / \mathrm{min} / \mathrm{g}$ of tissue. The results indicated that the ALKP activity in response to arsenic had been reduced significantly $(\mathrm{P}<0.05)$ by cold treatment when compared to arsenic treated fishes and also by control $(\mathrm{P}<0.01)$.

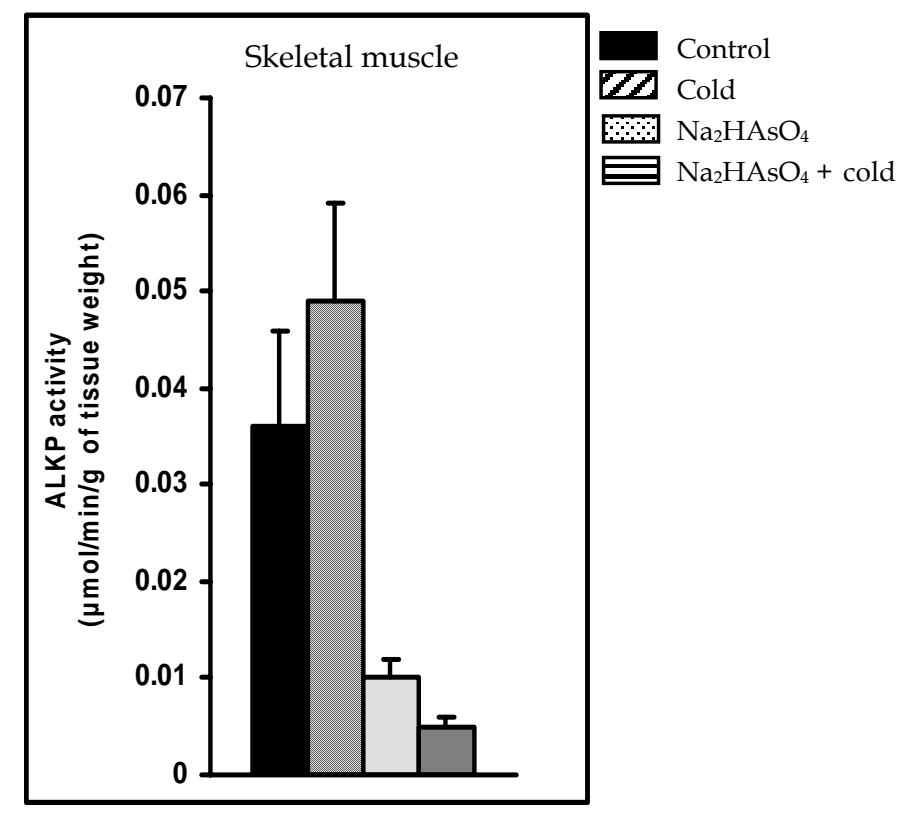

Fig. 1. Effects of $\mathrm{Na}_{2} \mathrm{HAsO}_{4}$ on ALKP level in skeletal muscle of fishes. The groups of fishes were treated with arsenic solution and kept for $1 \mathrm{hr}$ in the cold. The respective controls were treated with arsenic only while other fishes were exposed to cold for $1 \mathrm{hr}$. After the treatment, the fishes were immediately decapitated and sampling of tissue was performed. Control fishes were similarly used except giving cold exposure. The data are means \pm SE for 4 fishes in each group

\section{Role of arsenic (100 mM Na2HAsO4) on ALKP activity in cold-induced liver and GIT}

Liver ALKP is sensitive to toxic response and releases Pi from PNPP (p-nitro phenyl phosphate). To examine the role of arsenic on ALKP activity in liver, groups of fishes were treated with $100 \mathrm{mM} \mathrm{Na}_{2} \mathrm{HAsO}_{4}$ in cold for $1 \mathrm{hr}$ and the respective control livers were also examined with $\mathrm{Na}_{2} \mathrm{HAsO}_{4}$ only (Fig. 3). The ALKP activities in livers of groups of fishes in response to $100 \mathrm{mM} \mathrm{Na}_{2} \mathrm{HAsO}_{4}$ and in cold were $0.93 \pm 0.12 \mu \mathrm{mol}$ and $1.01 \pm$ $0.06 \mu \mathrm{mol}$ respectively while for control and cold exposed livers, the activities were $0.35 \pm$ $0.08 \mu \mathrm{mol}$ and $0.80 \pm 0.07 \mu \mathrm{mol} / \mathrm{min} / \mathrm{g}$ of tissue respectively. A significant increased response on ALKP activity was observed for fishes exposed to arsenic $(165.7 \%, \mathrm{P}<0.05)$ and also even in cold $(189.1 \%, \mathrm{P}<0.05)$ when the groups were compared to control. The results would suggest that both arsenic and cold environment create an adverse environment where the fishes survive by expressing their enzyme activity in this tissue. 


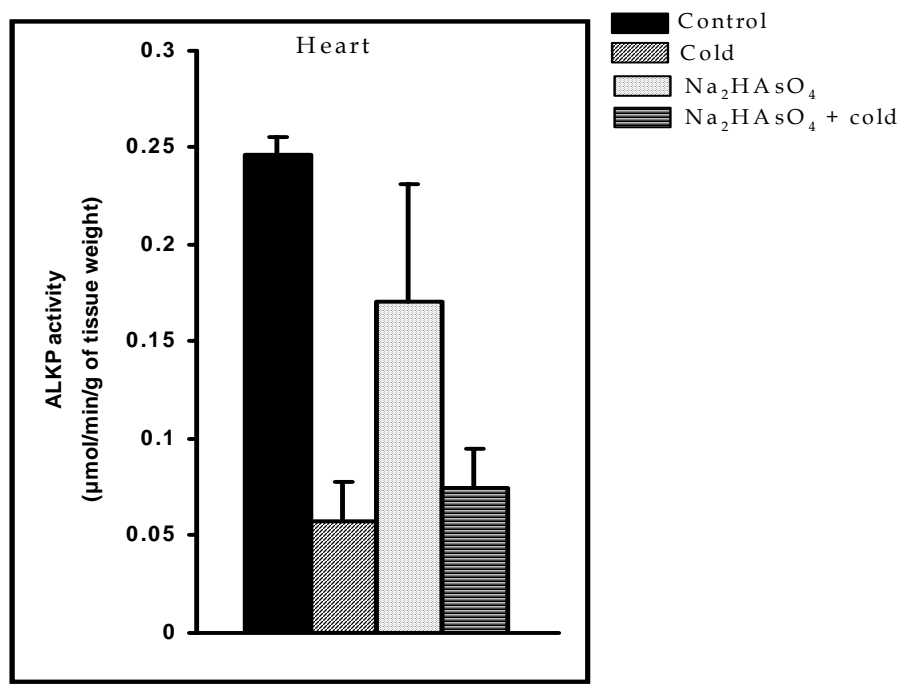

Fig. 2. Effects of $\mathrm{Na}_{2} \mathrm{HAsO}_{4}$ on ALKP level in heart muscle of fishes. The fishes were exposed to cold with arsenic solution for $1 \mathrm{hr}$. Other groups of fishes were treated with arsenic and exposed to cold for $1 \mathrm{hr}$ respectively. After the treatment, the fishes were immediately decapitated and sampling of tissue was performed. Control fishes were similarly used except giving cold exposure. The data are means \pm SE for 4 fishes in each group

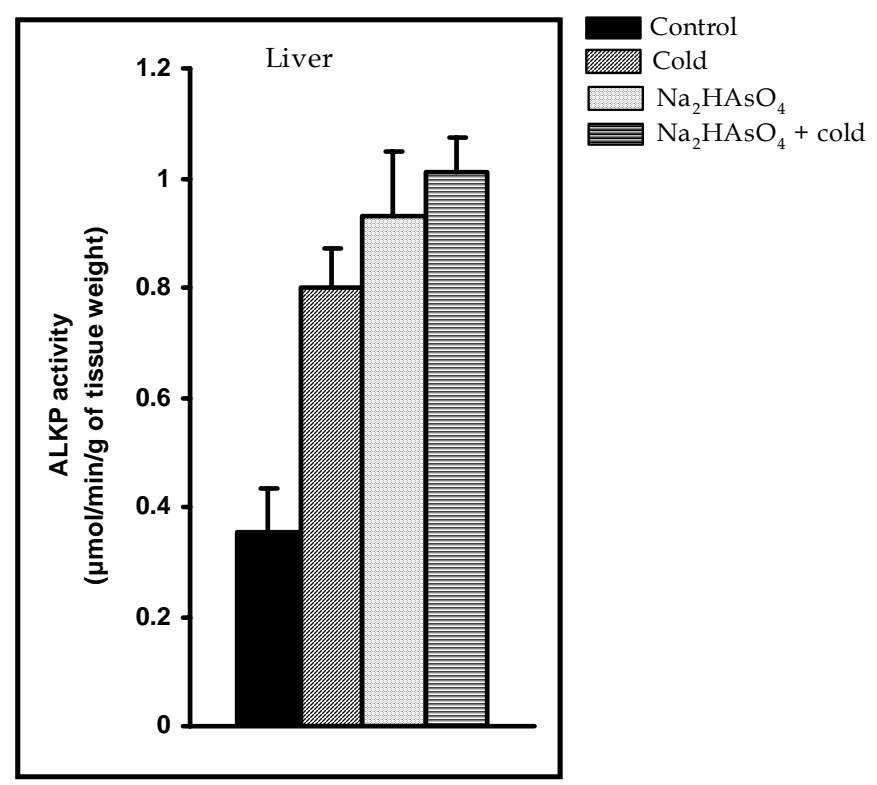

Fig. 3. Effects of $\mathrm{Na}_{2} \mathrm{HAsO}_{4}$ on ALKP activity in liver of fishes. The fishes were exposed to cold with arsenic solution for $1 \mathrm{hr}$. Other groups of fishes were treated with arsenic and exposed to cold for $1 \mathrm{hr}$ respectively. After the treatment, the fishes were immediately decapitated and sampling of tissue was performed. Control fishes were similarly used except giving cold exposure. The data are means \pm SE for 4 fishes in each group 
The ALKP activities in GIT (shown in Fig. 4) of fishes in response to $100 \mathrm{mM} \mathrm{Na}_{2} \mathrm{HAsO}_{4}$ and in cold were $0.239 \pm 0.03 \mu \mathrm{mol}$ and $0.243 \pm 0.04 \mu \mathrm{mol}$ respectively while for control and cold exposed fishes, the activities in GIT were $0.64 \pm 0.05 \mu \mathrm{mol}$ and $0.89 \pm 0.12$ $\mu \mathrm{mol} / \mathrm{min} / \mathrm{g}$ respectively. A significant reduced response on ALKP activity was observed for fishes exposed to arsenic $(62.6 \%, \mathrm{P}<0.05)$ when the groups were compared to control. Similar inhibitory effects $(62.0 \%, \mathrm{P}<0.001)$ were found when the fishes were exposed to cold with $\mathrm{Na}_{2} \mathrm{HAsO}_{4}$ for $1 \mathrm{~h}$, however, the effects were appeard to be potential than arsenic exposed fishes. The results indicate that the increased activity in response to cold is potentially reduced by $100 \mathrm{mM} \mathrm{Na} 2 \mathrm{HAsO}_{4}$; however, cold exposure did not overcome the stimulatory effect of higher concentration of arsenic compared to control fishes.

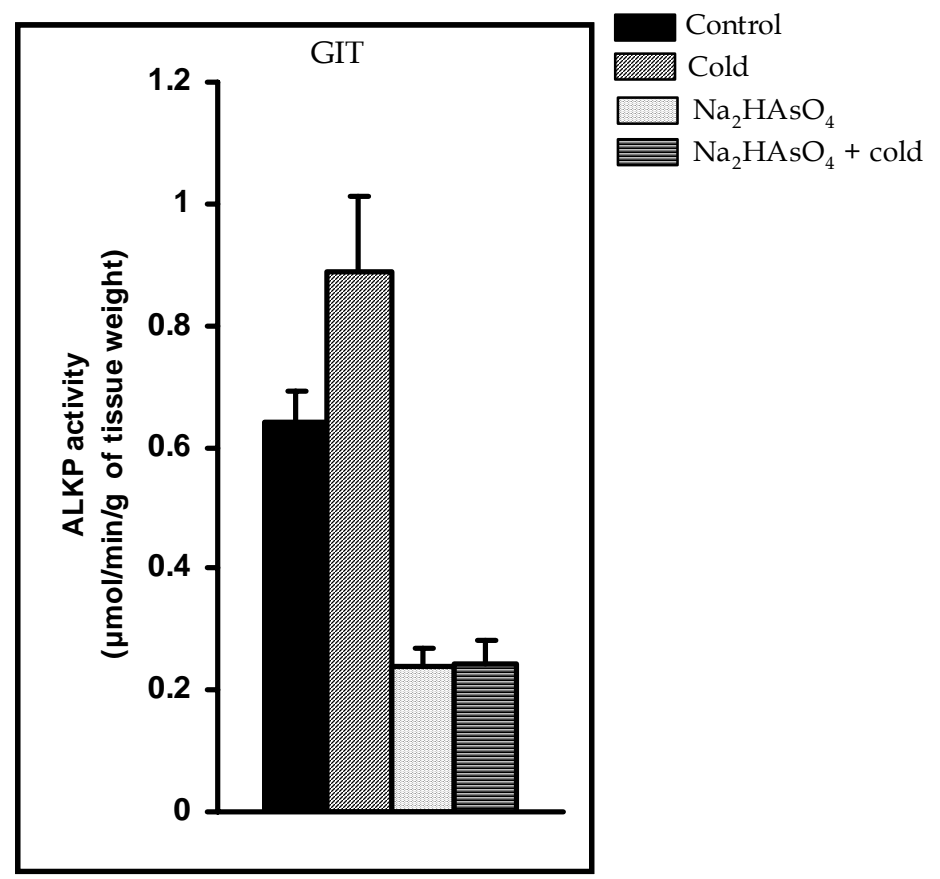

Fig. 4. Effects of $\mathrm{Na}_{2} \mathrm{HAsO}_{4}$ on ALKP activity in GIT of fishes. The fishes were exposed to cold with arsenic solution for $1 \mathrm{hr}$. Other groups of fishes were treated with arsenic and exposed to cold for $1 \mathrm{hr}$ respectively. After the treatment, the fishes were immediately decapitated and sampling of tissue was performed. Control fishes were similarly used except giving cold exposure. The data are means \pm SE for 4 fishes in each group

\section{DISCUSSION}

We found that ALKP activity is altered in certain peripheral tissues whenever the fishes were exposed to cold. In skeletal muscle and heart, ALKP activity is very low although these tissues are metabolically important. Several attempts to use conventional histochemical methods for detection of ALKP in skeletal muscle have failed to do at the 
light microscope level (Kirkeby and Moe, 1985), however, others attempted to localize ALKP at the ultra structural level in a skeletal muscle of a young rat (Asaad et al., 1991). Malhotra et al. (1978) found relatively higher levels of enzyme in the denervated muscle and also the proliferation of extrafibrillar connective tissue in the diseased muscle showing its specific association with the lytic processes. The above findings demonstrate that cold exposure augmenting higher sympathetic innervations will reduce the activity in muscle. Kar and Pearson (1972) also found the proliferation of non-contractile connective tissue with higher levels of alkaline phosphatase activity in the diseased human muscle and have assigned a lytic role to this enzyme. On the other hand, Dubowitz (1963) rules out the presence of this enzyme in normal muscle.

Heart muscle contains myosin and actin filaments but differ from skeletal muscle in that it is continuously active in a regular rhythm of contraction and relaxation. It is assumed from the current investigation that low temperature might be involved in reducing enzyme activity in heart during prolonged exposure of cold. Recent studies reveal that mitochondrial protein synthesis in rainbow trout heart is impaired by low temperature (West and Driedzic, 1999; Sephton and Driedzic, 1995). Therefore, the experimental results are supported by their findings.

The regulation of ALKP activity in the liver and GIT for cold-exposed fish might be a different mechanism than that of skeletal muscle and heart. Cold acclimation causes stimulation of ALKP activity in liver and GIT of the species. The major isozymes of ALKP include those of liver, bone and kidney and those of the intestine and the placenta; the isozymes of these two groups are each encoded by a separate gene (Toe et al., 1989; Weiss et al., 1989). Although this glycoprotein is widely distributed in vertebrate tissues, its physiological function is as yet fully understood. Liver is an organ where biotransformation of foreign toxic substances happens, because ALKP is predominantly found in liver and is an index of the characterization for liver pathogenesis. The higher activity of this enzyme in liver and GIT causes the release of Pi. The released Pi might be a molecule for survive in the atmosphere during energy deficiency.

The adverse effect of sodium arsenate $\left(\mathrm{Na}_{2} \mathrm{HAsO}_{4}\right)$ on metabolic regulation in cold induced fishes has been demonstrated. $100 \mathrm{mM} \mathrm{Na} 2 \mathrm{HAsO}_{4}$ produced the toxic environment where the fishes want to survive. Therefore, it is reasonable that an adaptive response by the species was created and some stress proteins are synthesized. Cold exposure was unable to reduce the toxic effect of arsenic whenever the fishes were exposed with $100 \mathrm{mM} \mathrm{Na}_{2} \mathrm{HAsO}_{4}$. The results clarify that this higher arsenic produces a severe effect on liver where the sympathetic nervous system does not play its role. The liver is the organ where most of the biotransformation of inorganic arsenic takes place (Del Razo et al., 2001). Up regulation of several genes in arsenic-induced adaptive response has been observed (Verma et al., 2002 and Chelbi-alix et al., 2003). Their findings suggest that arsenic may induce the synthesis of molecules responsible for the survival process. The liver is a major target organ of arsenic toxicity in both mice and humans. Arsenic-induced liver injury in humans is a common phenomenon, typically manifesting initially as degenerative lesions with jaundice, progressing to noncirrhotic portal 
hypertension, fibrosis, cirrhosis, and neoplasia such as hepatocellular carcinoma (Mazumder et al., 1998). Prolonged exposure of higher concentration of arsenic has been involved in liver injury and damage. Liver metabolism is a known potential target for the toxic action of chemicals (Hinton et al., 2001). Allen et al. (2004) found that arsenic impairs the sympathetic nerve activity induced by cold. ALKP is predominantly found in liver and is an index of the characterization for liver pathogenesis. The increased activity was observed by cold and enhanced time dependently. It is assumed that this enzyme is sensitive to cold or the activation of sympathetic nervous system is involved during cold acclimation. The released $\mathrm{Pi}$ might be influenced in response to low dose of arsenic because ALKP activity is augmented, however, the activity was appeared to be enhanced in cold. The results would indicate that metabolic function involving higher ALKP activity in liver is sensitive to this dose. Recent investigation reveals that arsenic exposure stimulated ALKP in liver (Sharma et al., 2007). The higher activity demonstrates that increased Pi release would be a survival factor during energy deficiency. Up regulation of genes associated with carbohydrate catabolism such as glycolysis and downstream genes associated with generation of precursor metabolites and energy clearly indicate a continuous need for production of precursor metabolites and energy to sustain various homeostatic and adaptive responses in the liver of arsenic-treated fish compared with the liver of control (non-treated) fish. The adverse effects caused by both low temperature and arsenic have been found in skeletal muscle and heart. Because these tissues express very low ALKP activity, therefore, it is assumed that in presence of these stimuli, the expression of this enzyme might be prevented. The cold induced activity in GIT was significantly inhibited by $100 \mathrm{mM} \mathrm{Na}_{2} \mathrm{HAsO}_{4}$. The results appeared to indicate that GIT metabolic functions are impaired whenever the fishes were exposed to such higher doses of arsenic. The fishes exposed to cold with arsenic had similar effects as arsenic alone which could be the toxic effects of $\mathrm{Na}_{2} \mathrm{HAsO}_{4}$.where the sympathetic nervous system induced by cold does not play the critical role on ALKP activity. On the other hand, both the adverse environments created by arsenic and cold might be involved in reducing the effect. It is assumed that intestinal motility and other necessary activities associated with excretion of waste materials like stool etc might be prevented by such doses of arsenic. Because exposure of cold has been found to be involved in the activation of ALKP activity in intestine, therefore, it is reasonably argued that arsenic might be involved in reducing the cold induced enzyme activity in this organ.

\section{CONCLUSION}

In summary, these peripheral tissues are metabolically important for energy consumption and energy expenditure. Environmental low temperature is a major stimulus exerting its effect on metabolic changes. However, the regulatory process in response to cold could be prevented or modulated by the toxic effects of arsenic. The diverse metabolic regulation in response to low temperature is an index for the survive of these species and is a useful biological process. However, arsenic probably takes part in modulation of the metabolic process. 


\section{ACKNOWLEDGEMENT}

This study was carried out in the Department of Biochemistry and Molecular Biology, Rajshahi University and was supported by the University Grant Commission (UGC), Bangladesh.

\section{REFERENCES}

Asaad, S., Erella, L., Michael, N. N. and Reznick, A. Z. 1991. Activity of alkaline phosphatase in rat skeletal muscle localized along the sarcolemma and endothelial cell membranes. J. Histochem. Cytochem., 39: 199-203.

Allen, T., Awasthi, A. and Rana, S. V. S. 2004. Fish Chromatophores as Biomarkers of Arsenic Exposure. Envir. Biol. Fish., 71(1): 7-11.

Bray, G. A. 1999. Sympathetic nervous system, adrenergic receptors, and obesity. J. Lab. Clin. Med., 134: 4-6.

Chelbi-alix, M. K., Bobe, P., Benoit, G., Canova, A. and Pine, R. 2003. Arsenic enhances the activation of Stat1 by interferon gamma leading to synergistic expression of IRF-1. Oncogene., 11: 9121-9130.

Dubowitz, V. 1963. Myopathic changes in muscular dystrophy carriers. Proc. R. Soc. Med., 56: 810-812.

Del Razo, L. M., Quintanilla-Vega, B., Brambila-Colombres, E., Calderon-Aranda, E. S., Manno, M. and Albores, A. 2001. Stress proteins induced by arsenic. Toxicol. Appl. Pharmacol., 177: 132-148.

Flechtner-Mors, M., Ditschu meit, H. H., Yip, I. and Adler, G. 1999. Sympathetic modulation of lipolysis in subcutaneous adipose tissue; effects of gender and energy restriction. J. Lab. Clin. Med., 134: 33-41.

Hughes, M. F. 2002. Arsenic toxicity and potential mechanisms of action. Toxicol. Lett., 133: 1-16.

Haque, M. S., Roy, S. K., Islam, M. A. and Roy, N. 2009. Role of arsenic on the regulation of glycogen metabolism in liver of Taki fishes (Channa Punctatus) exposed to cold. Thai J. Agric. Sci., 42 (3): 159-166.

Hinton, D. E., Segner, H. and Braunbeck, T. 2001. Toxic responses of the liver. In: Target Organ Toxicity in Marine and Freshwater Teleosts-Organs, edited by Schlenk D and Benson WH. London: Taylor and Francis, vol. 1, pp. 224-268.

Kirkeby, S. and Moe, D. 1985. Biochemical and histochemical studies of alkaline phosphatase in normal and dystrophic muscle. Exp. Pathol., 27 (3): 131-6.

Kar, N. C. and Pearson, C. M. 1972. Alkaline phosphatase in normal and diseased human muscle. Proc. Soc. Exp. Biol. Med., 141(1): 4-6.

Malhotra, R. K., Dhingra, S. and Katoch, S. S. 1978. Alkaline phosphatase activity in normal and denervated skeletal muscle. Cell. Mol. Life Sci., 34(9): 1206-1209.

Mazumder, D. N., Das Gupta, J., Santra, A., Pal, A., Ghose, A. and Sarkar, S. 1998. Chronic arsenic toxicity in west Bengal-the worst calamity in the world. J. Indian Med. Assoc., 96: 4-7.

Ramnik, S. 1999. Medical laboratory technology: Methods and interpretations. Jaypee Brothers, Medical publishers (P) Ltd., New Delhi, India. pp. 485-487. 
Sharma, A., Sharma, M. K. and Kumar, M. 2007. Protective effect of Mentha piperita against arsenic-induced toxicity in liver of Swiss albino mice. Basic Clin. Pharmacol. Toxicol., 100(4): 249-57.

Sephton, D. H. and Driedzic, W. R. 1995. Low temperature acclimation decreases rates of protein synthesis in rainbow trout (Oncorhynchus mykiss) heart. Fish Physiol. Biochem.,14(1): 63-69.

Toe, Y., Yamamoto, M., Endo, H., Mischin, Y. and Ikehara, Y. 1989. Isolation of and characterization of rat liver alkaline phosphatase gene. A single gene with two promoters. European J. Biochem., 182 (2): 231-7.

Tchounwou, P. B., Patlolla, A. K. and Centeno, J. A. 2003. Carcinogenic and systemic health effects associated with arsenic exposure-a critical review. Toxicol. Pathol., 31: 575-388.

Tisler, T. and Zagorc-Koncan, J. 2002. Acute and chronic toxicity of arsenic to some aquatic organisms. Bull. Envir. Contam. Toxicol., 69: 421-429.

Verma, A., Mohindru, M., Deb, D. K., Sassano, A., Kambhampati, S., Ravandi, F., Minucci, S., Kalvakolanu, D. V. and Platanias, L. C. 2002. Activation of Rac1 and the p38 mitogenactivated protein kinase pathway in response to arsenic trioxide. J. Biol. Chem., 277: 4498844995.

West, J. L. and Driedzic, W. R. 1999. Mitochondrial protein synthesis in rainbow trout (Oncorhynchus mykiss) heart is enhanced in sexually mature males but impaired by low temperature. J. Exp. Biol., 17 (202): 2359-2369.

Westfall, T. D., Sarkar, S., Ramphir, N., Westfall, D. P., Sneddon, P. and Kennedy, C. 2000. Characterization of the ATPase released during sympathetic nerve stimulation of the guineapig isolated vas deferens. British J. Pharmacol., 129(8): 1684-1688.

Weiss, M. J., Ray, K., Fallon, M. D., Whyte, M. P., Fedde, K. M., Lafferty, N. A., Mulivor, R. A. and Harris, H. 1989. Analysis of liver/bone/kidney alkaline phosphatase m-RNA, DNA and enzymatic activity in cultured skin fibroblasts from 14 unrelated patients with severe hypophosphatasia. American J. Hum. Genet., 44 (5): 686-694. 